\title{
Evaluation of hydrology, suspended sediment and Nickel loads in a small watershed in Basque Country (Northern Spain) using eco-hydrological SWAT model
}

\author{
M. Peraza-Castro ${ }^{1,2 *}$, E. Ruiz-Romera ${ }^{1}$, L.H. Montoya-Armenta ${ }^{1}$, J.M. Sánchez-Pérez ${ }^{3,4}$ \\ and S. Sauvage 3,4 \\ ${ }^{1}$ Department of Chemical and Environmental Engineering, Faculty of Engineering of Bilbao, University of the Basque Country \\ (UPV-EHU), Alameda de Urquijo s/n, E-48013 Bilbao, Spain \\ 2 School of Health Technologies, Faculty of Medicine, University of Costa Rica, Rodrigo Facio Campus, San Pedro de Montes de \\ Oca, San José, Costa Rica \\ 3 University of Toulouse, INPT, UPS, Laboratoire Ecologie Fonctionnelle et Environnement (Ecolab), Avenue de l'Agrobiopole, \\ 31326 Castanet Tolosan Cedex, France \\ 4 CNRS, Ecolab, 31326 Castanet Tolosan Cedex, France
}

Received 29 October 2013; Accepted 13 January 2015

\begin{abstract}
Suspended sediment transportation and associated pollutants from catchment to stream networks are responsible for aquatic habitat degradation, reservoir sedimentation and the transportation of sediment bound pollutants. Quantifying suspended sediment loads from lands to watercourses is essential in controlling soil erosion and in implementing appropriate mitigation practices to reduce stream sediment and associated pollutant loads, and hence improve surface water quality downstream. The main objective of this study is to evaluate the temporal variability of hydrology, sediment and nickel loads using Soil and Water Assessment Tool in Oka watershed located in north Spain. Model simulation was completed using 11 years historical records (2001-2009 for validation and 2009-2012 for calibration) of streamflow and suspended sediment concentration (SSC). Thestreamflow, SSC and sediment load estimated from the model were compared with observed data using statistical parameters, which indicates a successful simulation. The annual production of simulated sediments shows variability between 662 and $1515 \mathrm{t}$, with a mean specific yield of $33 \mathrm{t} \mathrm{km}^{-2} \mathrm{y}^{-1}$. The annual load of nickel simulated ranged from 32 to $72 \mathrm{~kg}$, representing a mean specific of $1.63 \mathrm{~kg} \mathrm{~km}^{-2}$ year $^{-1}$. The information obtained from this research is of interest to understand long term interannual variability of suspended sediment and nickel yield.
\end{abstract}

Key words: Streamflow / modeling / suspended sediment load / Nickel / SWAT / Oka catchment

\section{Introduction}

Watersheds are territorial units where the combination of a water system that produces water, simultaneously with an economic and social subsystem, activated by the human, capital, labor and technology works. They produce agricultural, livestock, forestry and recreational goods and services which are mainly demanded by the populations located downstream (IRENAT, 2002).

Recent worldwide legislation indicates a change in the role of the water in human development. In Europe, the Water Framework Directive (WFD) establishes new standards in the water body protection. The emphasis is an integrated approach in the management of watersheds as autonomous entities, while the WFD main objective is to

\footnotetext{
*Corresponding author:melissa.peraza@ucr.ac.cr
}

achieve a good ecological and chemical status of receiving waters by the year 2015 (Boskidis et al., 2012).

The watershed management actions are part of environmental management processes, as they have the purpose to contrast the negative environmental impacts and promote the positive. Some of these beneficial effects can be evaluated in terms of the quantity, quality, time and place where the water is captured.

Integrated Water Resources Management (IWRM) is a systematic process for assignment, monitoring and sustainable development of these resources, which promotes a more coordinated watershed management, the soil, the water and the interests of the upper and lower parts in a watershed. As a way to address water management in a given context, IWRM can use any instrument or tool available. Hydrological models are simplified representations of hydrologic systems and can be very useful 
tools for assessing water resources, a process aimed at achieving a comprehensive view of the status of these, and are therefore a baseline for IWRM (IRENAT, 2002).

Nowadays, the main threat to the deterioration of water bodies comes from non-point sources of pollution, as result of intensive agriculture and the development of urban areas (Boskidis et al., 2012). Sediment represents the largest volume of transported material. Others contaminants can be transported in association with sediment (absorbed contaminants) or in a solution (soluble contaminants) (FAO, 1993). The fine sediment may be an important vector for the transport of nutrients and pollutants, such as heavy metals (Ankers et al., 2003), pesticides and microorganisms.

The major source of heavy metals is anthropogenic activities, which are a hazard to aquatic biota and humans and are also a factor of water quality and environment deterioration. The river sediments - main reservoirs of heavy metals - act as secondary source of contamination of water bodies. This is why it is important to evaluate metals concentration as a tool to trace the origin of the pollutants in environment and predict impacts that may occur in aquatic ecosystems.

For this study, the heavy metal chosen is nickel (Ni). Ni is a natural constituent of soil; levels vary widely depending on local geology and anthropogenic input. $\mathrm{Ni}$ may be transported into streams and waterways from natural weathering of soil as well as from anthropogenic discharges and runoff. Much of this $\mathrm{Ni}$ is associated with particulate matter (ATSDR, 2005).

The sediment transport to the sea in the north Spain is produced in small-scale watershed. Authors as Zabaleta et al. (2007), Montoya-Armenta et al. (2013) have quantified the sediment load in two small watersheds in Basque Country and concluded that an increase in sediment transportation occurs during flood events. It is a very important challenge to quantify the amounts of sediments transported from land to the sea and to identity the erosion zones in order to improve the measurements that regulate pollutants that go from land to the river. In this regard, modeling is useful for assessing the impact of climate scenarios, crop management and land use on water and sediment yield without altering the watersheds environment.

The modeling helps to understand the hydrological behavior of a watershed as a basis for decision-making resource management, provides continuous predictions of water quality which reduces cost and time (Spruill et al., 2000), facilitates the simulation of the effects of conservation programs and helps to design policies to mitigate the degradation of water quality and soil (Moriasi et al., 2007).

Soil and Water Assessment Tool (SWAT) model was developed by USD-ARS (Agricultural Research Service) to predict the impact of land management practices on water, sediment and agricultural chemicals yields (nutrients and pesticides) in large complex watersheds with varying soil, land use and operating conditions over long periods of time (Arnold et al., 1987). SWAT model has been widely used as a tool due its friendly interaction with GIS and due its potential with regard to climate change issues, territorial planning and land use, watershed management, crop planning, assessment susceptible area to erosion, natural resources conservation and others; showing that it is a very helpful input to the process of decision making (Arroyo et al., 2010).

This study aims to apply agro-hydrological model SWAT to assess the temporal variability of the discharge, suspended solids concentration and sediment-associated $\mathrm{Ni}$ transport and to quantify annual sediment and $\mathrm{Ni}$ loads in the Oka River watershed (Basque Country, northern Spain).

\section{Materials and Methods}

\section{Study area}

The study area is located within the Oka Hydrographic Unit, bordered on the east and west by the valleys of the lea-Artibai and Butron, respectively. This Hydrographic Unit is divided into five watersheds: Oka, Golako, Mape, Artigas and Laga (http://www.uragentzia.euskadi.net).

The Oka River watershed is the backbone of the Hydrologic Unit; it is located in the province of Bizkaia, Basque Country and has its mouth at the Urdaibai estuary. It is the main contributor of continental water and sediment to the estuary. Its ecological wealth has being the main reason to be qualified as a biosphere reserve by UNESCO in 1984, receiving the name Biosphere Reserve Urdaibai.

Oka River has a short route of $14 \mathrm{~km}$ along the main axis. Its basin covers an area of approximately $31.56 \mathrm{~km}^{2}$, belonging to the region of Urdaibai. Born from the union of several streams from the Goroño, Oiz, Bizkargi and Arburu mountains, which converge at the level of Zugastieta - Oka, forming the main channel. Until Muxika it runs through a stony bed and small waterfalls. From here the slope become softer and therefore slows the river running (Bizkaia Provincial Council, 2012).

In the Muxika gauging station located at $20 \mathrm{~m}$ of elevation, average flow values have been recorded for the Oka River of $0.644 \mathrm{~m}^{3} \mathrm{~s}^{-1}$, with minimum of $0.05 \mathrm{~m}^{3} \mathrm{~s}^{-1}$ (September 9, 2006) and maximum of $20.89 \mathrm{~m}^{3} \mathrm{~s}^{-1}$ (August 26, 2002) for the hydrological years 1998-1999/ 2005-2006.

Hydrological data (discharge, Q), meteorological data (precipitation and temperature) and physicochemical data (turbidity, TRB; electrical conductivity, EC; and $\mathrm{pH}$ ) have been taken from the Muxika gauging station, which belongs to the Bizkaia Provincial Council (http://www. bizkaia.net). All previous mentioned data have been measured every 10 min since November 1998.

The Muxika gauging station records an average annual rainfall of $1238 \mathrm{~mm}$, with the highest values in autumn (150 $\mathrm{mm}$ average rainfall) and spring $(120 \mathrm{~mm})$, while in summer are collected about $42 \mathrm{~mm}$. Respect to the monthly rainfall average, December is recording the 

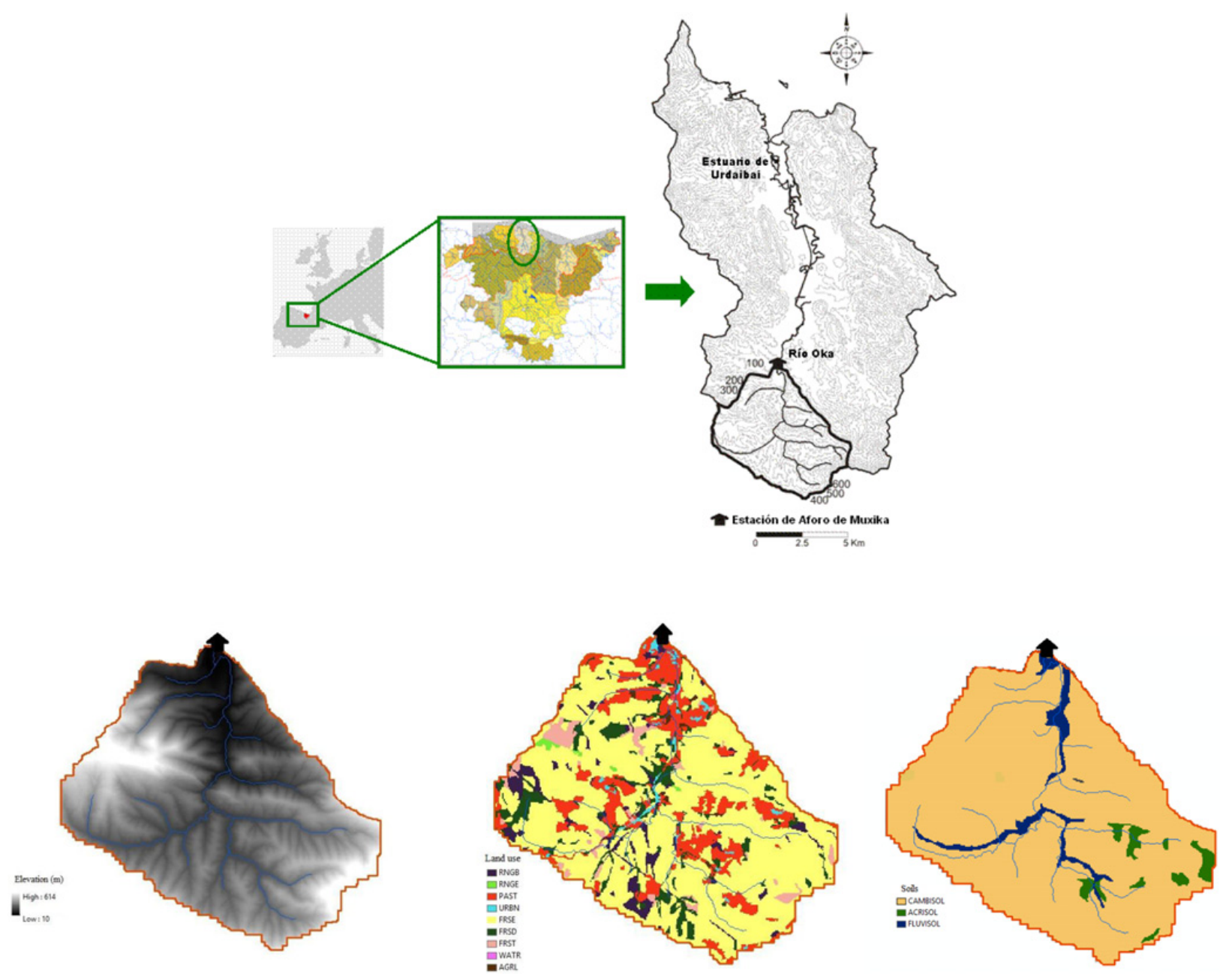

Fig. 1. Oka River catchment, location of the Muxika gauging station, topography, land uses and soil types map.

highest values $(153.9 \mathrm{~mm})$, followed by October $(153.2 \mathrm{~mm})$ and April $(124.7 \mathrm{~mm})$. By contrast, June is the one with the lowest rainfall $(34.6 \mathrm{~mm})$, followed by August $(36.6 \mathrm{~mm}$ ), exceeding always the $30 \mathrm{~mm}$ (Bizkaia Weather Network).

Regarding the relative humidity, it has been observed that during the first semester it varies between 40 and $90 \%$ with an average around $70 \%$. However, during the second half, values varies between 50 and $>90 \%$, with an average value around $80 \%$. Furthermore, the temperature during the first semester has values ranging between 5 and $20^{\circ} \mathrm{C}$, while in the second half varies between 15 and $>30^{\circ} \mathrm{C}$.

The elevation ranges from 13 to $605 \mathrm{~m}$. The main types of soils in the catchment are cambisols, followed by acrisols and fluvisols (Fig. 1). Oka River has its source in the Upper Cretaceous land formed by marls, clays and volcanic intrusions. In its lower part through Triassic land composed by ophites, loam, clay and plaster. In general, the waterways that drain to this basin are originate in sections of sandy limestone and calcareous substrates through floodplain bordered by stretches of clay, gypsum and basalts with Jurassic, Cretaceous and Tertiary outcrops.
The dedication of the basin, occupied by pine plantations, pastures and crops is mainly agricultural and forestry, except in the area of Gernika and surroundings, where there is a significant industrial activity (metallurgy, shipbuilding, chemical and preserves, among others). Only small patches of oak trees scattered around the basin. The head catchment has been mostly $(75 \%)$ reforested for industrial purposes with Pinus radiata and Eucalyptus sp., autochthonous vegetation (Quercus ilex) occupies around $12 \%$ and farmlands only $7 \%$ (Fig. 1 ).

\section{Field methodology}

Discharge $\left(\mathrm{Q}, \mathrm{m}^{3} \mathrm{~s}^{-1}\right)$, precipitation $(\mathrm{P}, \mathrm{mm})$, temperature $\left(\mathrm{T},{ }^{\circ} \mathrm{C}\right)$ and turbidity $(\mathrm{NTU})$ have been continuously monitored in the Muxika gauging station. This station comprises a crump profile single-crested weir. These variables were electronically logged at 10-min intervals. Turbidity was measured in the stream using a Solitax infrared backscattering turbidimeter with an expected range of 0-500 NTU. An automatic water sampler (SIGMA 900) has been installed in the gauging 


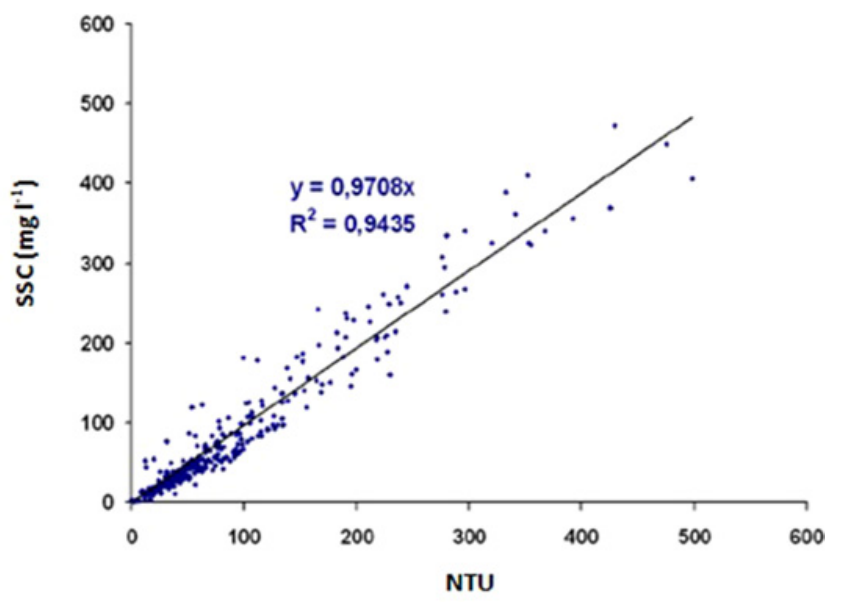

Fig. 2. Linear regression between field turbidity (NTU) and suspended sediment concentration (SSC) measured in the laboratory.

station and programmed to start pumping 24 one-litre water samples when turbidity in the stream rises 100 NTU, so the control of the flood events is guaranteed. The pumping frequency was of $2 \mathrm{~h}$ in all flood events. Data used for this study covers the period 2001-2012.

\section{Ni determination}

The Ni determination is obtained from sediment samples collected manually (according to the protocol US EPA, 2001) during flood events from 2009 to 2012, which were carried to Chemical and Environmental Engineering Laboratory (University of the Basque Country). The samples were pretreated according to the standard UNE 77303. In the digestion process is added to the sample $\mathrm{HNO}_{3}$ and $\mathrm{HCIO}_{4}$ and it is carried out using a digestion system by microwave (ETHOS1, Millestone). Then the sample was filtered through a preweighed $0.45 \mu \mathrm{m}$ Milipore nitrocellulose filter and drying at $105^{\circ} \mathrm{C}$ for $1 \mathrm{~h}$. $\mathrm{Ni}$ analyses were carried out using Inductively Coupled Plasma (ICP-OES) (Perkin Elmer Optima 2000).

\section{Determination of suspended sediment concentration (SSC) and Ni relationship}

A good lineal regression is obtained between NTU measured in field and SSC measured in the laboratory $\left(\left(R^{2}=0.94\right)\right.$. As well, continuous data of SSC were obtained by the relationship SSC $=0.9708 \times$ NTU (Fig. 2).

With the Ni and SSC data obtained in the laboratory, a relationship was established between SSC and Ni, obtaining $R^{2}=0.88$. Based on this relationship: $\mathrm{Ni}=0.2219 \times$ (SSC ${ }^{0.6659}$ ) (Fig. 3), the long term Ni concentration could be computed from simulated SSC obtained from SWAT.

Once the simulated SSC are calibrated, the relationship will be used to calculate simulated $\mathrm{Ni}$ concentration on a daily scale and annual load. Over others heavy metal, $\mathrm{Ni}$ was chosen because of its good correlation with SSC and for having a first approach between heavy metals and SWAT.

\section{Modeling Approach}

\section{SWAT model}

The SWAT was developed by Agricultural Research Service (USD-ARS) to predict the impact of land management and vegetation in the production of water, sediment and agricultural chemicals in watersheds with varying soils, land use and management conditions in long periods of time (Arnold et al., 1998).

It is an agro-hydrological physically based model, that is, instead of integrating regression equations to describe relationships between input and output variables, SWAT requires specific information about weather, soil physical properties, topography, vegetation and land management practices (Torres et al., 2003).

It is a semi-distributed model that divides the watershed into sub-watersheds, and each sub-watershed is subdivided, in turn, into hydrological response units (HRU). Each HRU is a homogeneous combination of slope, soil type and land use.

SWAT is able to operate on a daily, monthly and yearly time step. Provides information about hydrology, sediments, nutrients ( $\mathrm{N}$ and $\mathrm{P}$ ), bacteria and pesticides in the exit points of each sub basin or HRU, also allows additional control points placed within the study area. The model uses as interface a geographic information system (GIS) that provides spatial data, including soil, vegetation cover, climate and topographical features.

Theory and details of the different processes integrated in the SWAT model are available online in (Arnold et al., 2011; Winchell et al., 2010) http://swatmodel.tamu.edu.

\section{SWAT input data}

The SWAT model requires input such as topography, soil, land use and meteorological data.

- Digital Elevation Map (DEM) with a special resolution of $90 \mathrm{~m} \times 90 \mathrm{~m}$ from NASA. The model delineates the catchment and generates sub-basins and HRU based on the DEM. In this case, the Oka River watershed was discretized into 23 sub-basins and 260 HRUs. It also provides topographic parameters such as slope, which was classified into three ranges: $0-5 \%, 5-20 \%$ and $>20 \%$.

- Soil data at scale of 1:25.000 from www.geo.euskadi. net. The soil classes were simplified using the characteristics of the dominant soils. Soils in the upper catchment are predominantly Humic Cambisols $(92 \%)$, Acrisols (3\%) and Eutric Fluvisols (5\%) in the near-stream areas. The soils are a determining factor in hydrological processes such as surface runoff, 


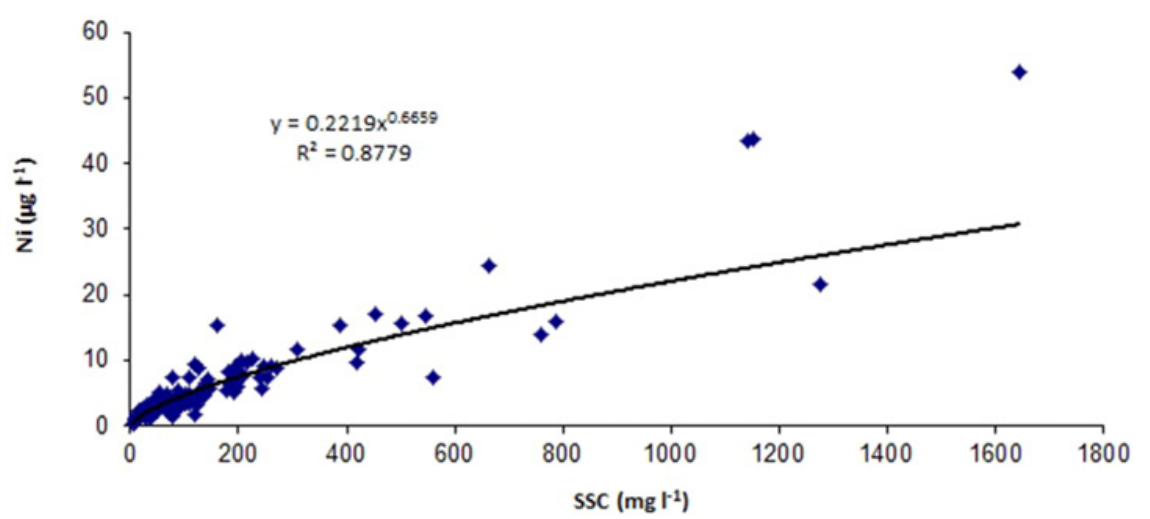

Fig. 3. Relationship between suspended sediment (SSC) and nickel concentration.

infiltration, percolation, lateral sub-surface flow, water available for plants.

- Land use data at scale of 1:10000 from Forest Inventory CAV, (GeoEuskadi, 2005). Land use determines various components of the hydrological cycle as total water requirement, irrigation demand, consumption by evapo-transpiration, surface runoff, leaching and erosion. The use of the basin is mainly distributed in Forest-Evergreen (FRSE $=66 \%$ ), Pasture (PAST = $16 \%)$, Forest-Deciduous (FRSD $=8 \%$ ), Range-Brush $(\mathrm{RNGB}=5 \%), \quad$ Forest-Mixed $\quad(\mathrm{FRST}=4 \%) \quad$ and Residential (URBN $=1 \%$ ).

- Meteorological data as maximum and minimum temperature and daily precipitation were obtained from the Muxica station (C063) through Euskalmet (20012012). In our case, Hargreaves equation was selected for Potential Evapotranspiration (PET) computation.

\section{Model evaluation}

Statistical methods such as coefficient of determination $\left(R^{2}\right)$ and index of agreement $(d)$ were used to evaluate the model performance (Krause et al., 2005) with respect to the simulation of streamflow, sediment and $\mathrm{Ni}$.

Furthermore, the graphical comparison between observed data and simulation results provides a first insight into the model functioning (ASCE, 1993).

$$
\begin{aligned}
R^{2} & =\left(\frac{\sum_{i=1}^{n}\left(O_{i}-\bar{O}\right)\left(P_{i}-\bar{P}\right)}{\sqrt{\sum_{i=1}^{n}\left(O_{i}-\bar{O}\right)^{2}} \sqrt{\sum_{i=1}^{n}\left(P_{i}-\bar{P}\right)^{2}}}\right)^{2} \\
d & =1-\frac{\sum_{i=1}^{n}\left(O_{i}-P_{i}\right)^{2}}{\left.\sum_{i=1}^{n}\left(\left|P_{i}-\bar{O}\right|\right)+\left|O_{i}-\bar{O}\right|\right)^{2}}
\end{aligned}
$$

where $O$ and $P$ are the observed and simulated value respectively, $n$ is the total number of paired values, $\bar{O}$ is the mean observed value and $\bar{P}$ is the mean simulated value.

The coefficient of determination $\left(R^{2}\right)$ value indicates the consistency with which measured versus predicted values follow a best fit line. It ranges from 0 to 1 . If the value is equal to 1 , the prediction model is considered "perfect". $R^{2}$ only describes how much of the observed dispersion is explained by the prediction.

The index of agreement $(d)$ was proposed by Willmot (1981) and represents the ratio of the mean square error and the potential error (Willmot, 1984). The range of $d$ is similar to that of $R^{2}$.

The model simulation performance is classified according to Parajuli et al., 2009: Excellent $>0.90$, Very good 0.75-0.89, Good 0.50-0.74, Fair 0.25-0.49, Poor 0.00-0.24 and Unsatisfactory $<0.00$.

\section{Calibration and validation process}

The period from October 2000 to September 2001 served as warm up for the model (allowing state variables to assume realistic initial values for the calibration period). The validation period corresponded to October 2001 to September 2009 and the calibration period to October 2009 to September 2012. Both the calibration and the validation were performed at daily scale using streamflow $\left(\mathrm{m}^{3} \mathrm{~s}^{-1}\right)$ and SSC $\left(\mathrm{mgl}^{-1}\right)$ data measured at the Muxica gauging station (located at the basin outlet) during ten hydrological years.

The capability of a hydrological model to adequately simulate stream flow and sediment processes typically depends on the accurate calibration of parameters (Xu et al., 2009). Parameters can either be estimated manually or automatically. In this study, the calibration was performed manually based on physical catchment knowledge of the basin, in sensitive parameters from published literature (Oeurng et al., 2011; Zabaleta et al., 2013) and calibration techniques from the SWAT user manual.

Firstly, the hydrology calibration is performed and subsequently the sediments, as these are dependent on hydrology.

The parameters used in the manual calibration of streamflow and sediments are presented in Table 1. The saturated hydraulic conductivity (Sol_K) is a measure of the ease of water movement through the soil. SCS curve number (CN2) is a function of soil permeability, land use and antecedent condition of soil water. This parameter is 
Table 1. Parameters used to calibrate streamflow and sediments at Muxica station.

\begin{tabular}{|c|c|c|c|c|c|}
\hline File & Parameter & Definition & $\begin{array}{l}\text { Min. } \\
\text { value }\end{array}$ & $\begin{array}{l}\text { Max. } \\
\text { value }\end{array}$ & $\begin{array}{c}\text { Calibrated } \\
\text { value }\end{array}$ \\
\hline \multicolumn{6}{|c|}{ Parameters used to calibrate stream flow } \\
\hline \multirow[t]{4}{*}{. $\mathrm{GW}$} & ALPHA_BF & Baseflow alpha factor & 0 & 1 & 0.021 \\
\hline & GWDELAY & Groundwater delay & 0 & 500 & 150 \\
\hline & SHALLST & Initial depth of water in the shallow aquifer & 1000 & 50000 & 1000 \\
\hline & RCHRG_DP & Deep aquifer percolation fraction & 0 & 1 & 0 \\
\hline.$b s n$ & $\mathrm{ESCO}-$ & Soil evaporation compensation factor & 0 & 1 & 1 \\
\hline mgt & $\mathrm{CN} 2$ & SCS Curve number & 35 & 98 & $\uparrow 10 \%$ \\
\hline \multirow[t]{2}{*}{ soil } & SOL_AWC & Available water capacity of the soil layer & 0 & 1 & 0.26 \\
\hline & $\mathrm{SOL}_{-} \mathrm{K}$ & Saturated hydraulic conductivity & 0 & 400 & $\uparrow 10 \%$ \\
\hline.$h r u$ & $\mathrm{OV} \_\mathrm{N}$ & Manning's " $N$ " for overland flow & 0.01 & 0.5 & 0.6 \\
\hline .rte & CH_N2 & Manning's " $n$ " value for main channel & -0.01 & 0.3 & 0.04 \\
\hline. sub & CH_N1 & Manning's " $n$ " value for tributary channels & 0.01 & 0.5 & 0.035 \\
\hline \multicolumn{6}{|c|}{ Parameters used to calibrate sediments } \\
\hline soil & USLE_K & USLE soil erodibility factor & 0 & 0.65 & 0.20 \\
\hline. $\mathrm{mgt}$ & USLE_C & USLE support practice factor & 0 & 2 & 0.80 \\
\hline \multirow[t]{2}{*}{.$b s n$} & SPEXP & Exponent parameter for calculating the channel sediment routing & 1 & 2 & 2 \\
\hline & PFR & Peak rate adjustment factor for sediment routing & 0 & 2 & 0.50 \\
\hline .hru & LAT_SED & Sediment concentration in lateral and groundwater flow & 0 & 5000 & 5 \\
\hline
\end{tabular}

Table 2. Summary efficiency criteria obtained.

\begin{tabular}{|c|c|c|c|c|c|c|}
\hline & \multicolumn{3}{|c|}{ Validation } & \multicolumn{3}{|c|}{ Calibration } \\
\hline & Streamflow & SSC & Sediment load & Streamflow & SSC & Sediment load \\
\hline$R^{2}$ (coefficient of determination) & 0.63 & 0.28 & 0.36 & 0.71 & 0.28 & 0.70 \\
\hline$d$ (index of agreement) & 0.88 & 0.66 & 0.58 & 0.92 & 0.70 & 0.80 \\
\hline
\end{tabular}

important for surface runoff. The baseflow recession coefficient (ALPHA_BF) is a direct index of groundwater flow response to changes in recharge. This parameter is necessary for baseflow calibration.

The sensitive parameters for sediment predictions are the exponential parameter for calculating the sediment transport in the channel (SPEXP) and adjust factor of maximum sediment transport rate (PRF), which is sensitive to sediment peaks.

\section{Results and discussion}

\section{Results analysis}

In first place, in order to determine sediment dependence with regard to streamflow, proceed to calculate sediment load from the product of SSC and flow. Observed SSC was estimated from turbidity (NTU) as mentioned Section 'Determination of $\mathrm{SSC}$ and $\mathrm{Ni}$ relationship'. Observed streamflow, SSC and sediment load matched with the simulated values, respectively.

The results obtained have been compared with efficiency criteria (Table 2). In general terms, the results are satisfactory. The coefficient of determination gives acceptable results. However, during the validation period of sediment, the values decrease. It is why is used the index of agreement, which shows better results because overcome the insensitivity of coefficient of determination to differences in the observed and predicted means and variances
(Legates and McCabe, 1999). Values demonstrate that the flow fits better than the sediments and the sediments fits better in terms of load than concentration, which is not unusual according Santhi et al. (2001); Moriasi et al. (2007).

\section{Streamflow simulation and hydrological assessment}

With regard to water balance, the model predicts a mean annual rainfall for the entire simulation period of $1171 \mathrm{~mm}$, which $559 \mathrm{~mm}(48 \%)$ is the water production and $629 \mathrm{~mm}(52 \%)$ is removed by evapotranspiration.

Figure 4 corresponds to graphical results of modeling. Figure 4(a) illustrates observed and simulated daily streamflow. The simulated flow follows a similar trend to that observed and the peaks correspond to precipitation events. Some peaks simulated flow does not have sufficient intensity to reach the observed flow peaks. The underestimation of streamflow peaks might be due to localized rainfall event was not properly represented by the rainfall data used in hydrologic simulation. These inaccuracies, according to Qiu et al. (2012), could be related with the SWAT inability to simulate precipitation patterns in terms of intensity and temporal distribution.

For the whole study period, the gauging station recorded a mean flow of $0.65 \mathrm{~m}^{3} \mathrm{~s}^{-1}$, which is comparable with the mean simulated value of $0.57 \mathrm{~m}^{3} \mathrm{~s}^{-1}$.

Annual rainfall shows a high temporal variability. The year 2008/2009 was the rainiest with a rainfall volume of $1445 \mathrm{~mm}$ and the driest 2001/2002 with $938 \mathrm{~mm}$. 

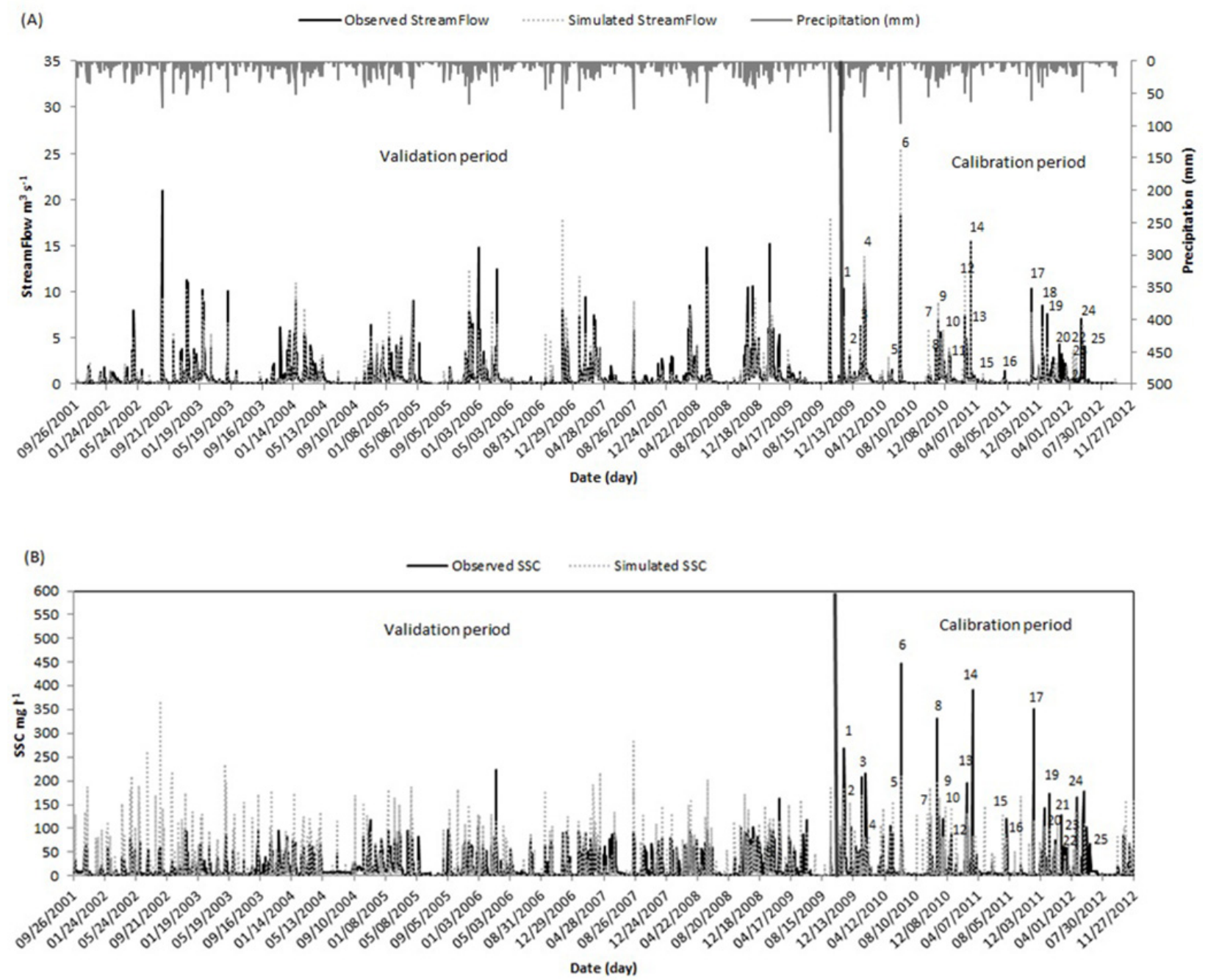

Fig. 4. Daily streamflow calibration, validation, precipitation and flood events identification (a) and daily suspended sediment concentration (SSC) calibration, validation and flood events identification (b) at Muxica Station (October 2001 to September 2012).

Montoya-Armenta (2013) analyzed for the period 2009-2012 - at hourly scale - 25 flood events and classified them in low, medium and high intensity according to stream flow intensity and sediment exported.

- Type I: Flood events of low intensity are the most common in this catchment $(48 \%)$, represented for twelve events $(2,5,7,11,13,15,16,20,21,23,24$ and 25). In general, the maximum peak flow is achieved in less than $24 \mathrm{~h}$, with a flow point below $10 \mathrm{~m}^{3} \mathrm{~s}^{-1}$ and a low sediment contribution (100 t).

- Type II: Flood events of medium intensity represents the $36 \%$ of analyzed events, with nine generated events $(3,4,8,9,10,12,18,19$ and 22), have relatively short generation times, peak flow ranges between 10 and $21 \mathrm{~m}^{3} \mathrm{~s}^{-1}$ and have a considerable relevance sediment loads $(100 \mathrm{t} \leq \mathrm{SSt} \leq 500 \mathrm{t})$.

- Type III: Flood events of high intensity presents four events: 1, 6, 14 and $17(16 \%)$. The event 1 is classified as one of very long duration. The remaining three events $(6,14$ and 17) were shorter but their high intensity catalogs them as exceptional. They present intense peaks flows $\left(21-60 \mathrm{~m}^{3} \mathrm{~s}^{-1}\right)$ and sediment exportation is considerably high $(>500 \mathrm{t}$ ).

\section{SSC simulation and yield}

Regarding the SSC (Fig. 4(b)), similar trends were found between observed and simulated data. During calibration period, the SSC was underestimated and overestimated during some flood events. The underestimation occurs for four events that according to MontoyaArmenta (2013) drag a greater amount of sediment suspended: 1, 6, 14 and 17 occurred on November 8, 2009, June 15, 2010, March 16, 2011 and November 6, 2011, respectively. In practice, precipitation of high intensity and short duration may generate more sediment than simulated by the model based on daily rainfall $(\mathrm{Xu}$ et al., 2009). According to Benaman and Shoemaker (2005), SWAT tends to underestimate the amount of 


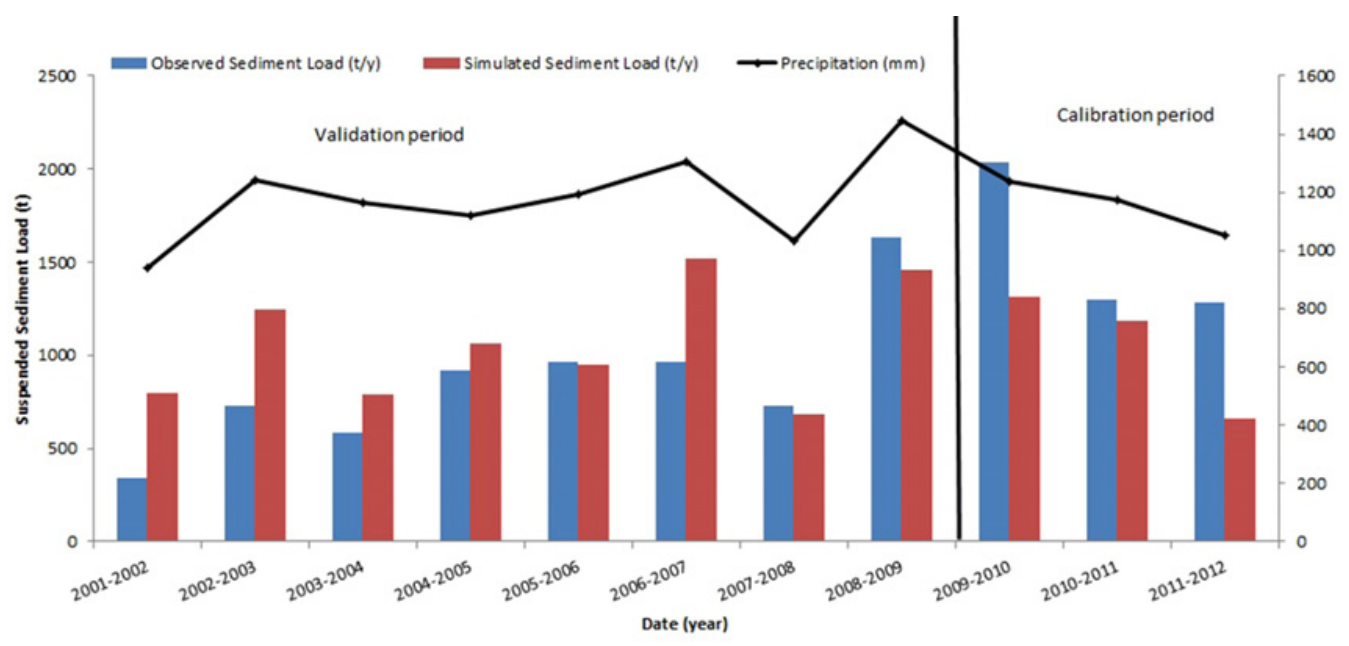

Fig. 5. Observed and simulated annual sediment load from October 2001 to September 2012.

sediment in high intensity events. Overestimation occurred, for example, in events 2, 10, 11 and 23.

Daily SSC ranges between 1.43 and $370 \mathrm{mg} \mathrm{L}^{-1}$, with a mean specific of $14 \mathrm{mg} \mathrm{L}^{-1}$, comparable with an observed mean of $13 \mathrm{mg} \mathrm{L}^{-1}$.

The simulation of discharge and suspended sediments follows the trend reported by Montoya-Armenta, (2013).

The simulated annual sediment load showed variability between 662 and $1515 \mathrm{t}$, representing a mean specific of $33 \mathrm{t} \mathrm{km}^{-2} \mathrm{y}^{-1}$. At the level of Spain, the annual sediment exportation is lower than reported by Walling and Webb (1996) for Mediterranean basins of the Iberian Peninsula (100-250 t km $\mathrm{km}^{-2}$ ). As for the Basque Country main basins, there are clear differences between each other, depending on its size and topography. Uriarte (1998) made a study in the Gipuzkoa province and reported sediment exportation rates with values of 45,55 and $50 \mathrm{t} \mathrm{km}^{-2} \mathrm{y}^{-1}$ for the basins of Deba $\left(450 \mathrm{~km}^{2}\right)$, Urola $\left(280 \mathrm{~km}^{2}\right)$ and Urumea $\left(210 \mathrm{~km}^{2}\right)$, respectively. Moreover, Oiartzun and Oria catchments hold higher exportation rates, with 130 and $260 \mathrm{t} \mathrm{km}^{-2} \mathrm{y}^{-1}$, respectively. Zabaleta et al. (2007), who analyzed the hydro-sediment response in small basins of Gipuzkoa, estimates sediment exportation rates of 45, 35 and $15 \mathrm{t} \mathrm{km}^{-2} \mathrm{y}^{-1}$, respectively for Añarbe $\left(48 \mathrm{~km}^{2}\right)$, Aixola $\left(4.8 \mathrm{~km}^{2}\right)$ and Barrendiola $\left(3 \mathrm{~km}^{2}\right)$ watersheds. This author also notes that it is difficult to make a comparison between the results obtained for different basins, as there are significant differences between the methodologies used by the authors and the watershed characteristics (geology, topography, precipitation, land use, among other).

During validation period, in 2009/2010, the sediment yield was the highest $(1456 \mathrm{t})$ and in turn the wettest (1445). The year 2001/2002 produced the lowest sediment yield (796 t) and presented the lower rainfall $(938 \mathrm{~mm})$.

During calibration period, the sediment yield in 2009/ 2010 was the highest (1315 t), can be explained because two of the highest intensity flood events that exported more sediment ( 1 and 6 ) occurred in this period and also were the years with highest volume of precipitation (1235).
The year with the lowest sediment yield (661 t), and in turn the lower rainfall $(1050 \mathrm{~mm})$, was $2011 / 2012$. There is an interannual variability in sediment yield for the study period, which indicates a relationship with precipitation (Fig. 5).

Such variability in sediment yield resulting from hydrological fluctuations between seasons every year. For this catchment, Montoya-Armenta (2013) concluded that sediment transportation is controlled by the total rainfall, the flood event flow and total water production.

During the hydrological year 2009/2010 occurred six flood events (1, 2, 3, 4, 5 and 6); two of them are of special interest. The longest flood event (1) occurred on November 1, 2009. This event reached in the simulation, peaks stream flow of $5.76 \mathrm{~m}^{3} \mathrm{~s}^{-1}$, a maximum sediment concentration of $172 \mathrm{mg} \mathrm{L}^{-1}$ and a sediment load of 85 tones.

Another case of maximum stream flow and sediment concentration took place in June 2010 (event 6), with a high intensity event that stands out among all the events occurred during the study period. This extreme flood event recorded a flow and sediment concentration simulated peak of $25 \mathrm{~m}^{3} \mathrm{~s}^{-1}$ and $174 \mathrm{mg} \mathrm{L}^{-1}$, respectively, the highest of all episodes analyzed in the years 2009-2012. This event is the largest contributor to the simulated sediment yield with 383 tones, which can be explained by its intensity and greater availability of material accumulated in the previous four and half months, during which there were no episodes of heavy rains that create flood events of consideration. The remaining four events are considered medium (January 2010, events 3 and 4) to low intensity (December 2009 and May 2010, events 2 and 5).

During the hydrological year $2010 / 2011$, ten flood events were analyzed $(7,8,9,10,11,12,13,14,15$ and 16). In this year, flood event 14 (March 16, 2011) stands out. This event boasted a simulated peak stream flow of $15 \mathrm{~m}^{3} \mathrm{~s}^{-1}$, among the observed data this was the second most important event. This flood event presented a sediment concentration peak of $85 \mathrm{mg} \mathrm{L}^{-1}$. It also contributed largely to sediment yield for this year with 114 tones. 
The events occurred in November 2010 (8, 9 and 10) and February 2011 (12 and 13), are the next in order of importance due its water contribution, despite being less intense. In November, the flood event 9 is the most important for its duration, presented a simulated peak flow of $5.37 \mathrm{~m}^{3} \mathrm{~s}^{-1}$, maximum sediment concentration of $138 \mathrm{mg} \mathrm{L}^{-1}$ and a sediment yield of 64 tones.

Flood event 7, despite being a low intensity event, has a high sediment concentration $\left(182 \mathrm{mg} \mathrm{L}^{-1}\right)$, which can be attributed to a greater availability of material accumulated during the previous months. Flood events of low and medium intensity can also generate high SSCs. This happens depending on the variability in sediment availability within the watershed, rainfall intensity and spatial distribution, discharge, types and distances traveled by water in the main channel, which determine the response of suspended sediment (Williams, 1989; NadalRomero et al., 2008; Sadeghi et al., 2008; RodríguezBlanco et al., 2010).

In the February, the flood event 12 stood out. Of shorter duration, had a flow peak and sediment concentration of $12 \mathrm{~m}^{3} \mathrm{~s}^{-1}$ of $105 \mathrm{mg} \mathrm{L}^{-1}$, respectively and a sediment load of 108 t. In July 2011 there were two consecutive events (15 and 16) characterized as being of low intensity.

Finally, in the hydrological year $2011 / 2012$, there were nine floods events $(17,18,19,20,21,22,23,24$ and 25). This year was characterized by periods of consecutive events, mainly from December 2011 to February 2012 (events of 17-21) and during the months of April and May 2012 (events of 22-25). The most important hydrological event (17) occurred on November 6, 2011, with a simulated stream flow peak of $8 \mathrm{~m}^{3} \mathrm{~s}^{-1}$, a sediment concentration peak of $104 \mathrm{mg} \mathrm{L}^{-1}$, and is the event that contributes with greater amount of sediment during this year with 70 t. After this event, is another of interest (event 18), with a simulated flow peak of $6 \mathrm{~m}^{3} \mathrm{~s}^{-1}$, sediment concentration of $105 \mathrm{mg} \mathrm{L}^{-1}$ and a load of $55 \mathrm{t}$. Subsequently, new events happened but of lower intensity. Table 3 summarizes the flood events occurred every hydrologic year.

\section{Ni concentration simulation and yield}

Within the study period of floods, the maximum concentration of $\mathrm{Ni}\left(210 \mu \mathrm{g} \mathrm{L}^{-1}\right)$ is presented for flood event 6 occurred on June 15, 2010. For other high intensity flood events 1, 14 and 17 concentrations were of 7, 4 and $5 \mu \mathrm{g} \mathrm{L}^{-1}$, respectively. For whole simulation period, Ni

Table 3. Occurrence of flood events during 2009-2012.

\begin{tabular}{ll}
\hline Hydrological year & \multicolumn{1}{c}{ Flood events } \\
\hline $2009-2010$ & $1,2,3,4,5,6$ \\
$2010-2011$ & $7,8,9,10,11,12,13,14,15$ y 16 \\
$2011-2012$ & 8,9 y 10 \\
\hline
\end{tabular}

concentration varied from 0.28 to $11 \mu \mathrm{g} \mathrm{L}^{-1}$, with a mean of $0.97 \mu \mathrm{g} \mathrm{L}^{-1}$ (Fig. 6(a)), comparable with an observed mean of 1 .

In Spain, some rivers have higher Ni concentrations, for example, the Guadalquivir river in Andalusia with $2.31 \mathrm{~g} \mathrm{~L}^{-1}$ (Mendiguchía et al., 2007), others are more contaminated by metals, so is the case of rivers Odiel and Tinto (163 and $170 \mu \mathrm{g} \mathrm{L}^{-1}$, respectively) discharging its waters into the Huelva estuary in Andalusia (Cánovas et al., 2009) or Meca River in Huelva with $252 \mu \mathrm{g} \mathrm{L}^{-1}$ (Galván et al., 2009). Similarly, many rivers in different places in the world have higher concentrations of metals in the water. This is the case of Odra, an agricultural and industrial basin in the Czech Republic (Rybicka et al., 2005 ) with a mean concentration of $5.19 \mu \mathrm{g} \mathrm{L}^{-1}$.

Observed and simulated values were statistically satisfactory at daily time scale (validation $R^{2}=0.33, d=0.73$ and calibration $\left.R^{2}=0.33, d=0.75\right)$.

The simulated annual Ni load ranged from 32 to $73 \mathrm{~kg}$, representing a mean specific Ni yield of $1.63 \mathrm{~kg} \mathrm{~km}^{-2}$ year $^{-1}$ (Fig. 6(b)). The studied basin exports less Ni load compared with others of Spain, such as the Tinto and Odiel rivers in Andalusia with 2 and 32 tons $\mathrm{y}^{-1}$, respectively (Olías et al., 2006).

The hydrological year 2008-2009 exported in total $73 \mathrm{~kg}$ of Ni. This year had the highest Ni exportation over the others years; such it is closely related to sediment yield in the study period. The year 2001-2002 presented the lower Ni load with $32 \mathrm{~kg}$. In general, Ni load variability is due to the variability associated with SSC within the catchment.

\section{Conclusions}

The model parameterisation achieves good simulations at daily scale in relation to streamflow, suspended sediment and $\mathrm{Ni}$.

One of the determining factors in simulation accuracy is the closeness of hydro-meteorological station with the boundary watershed. It should be noted that this setting is achieved in a preserved watershed, small in size and with homogeneous vegetation.

Sediment transportation is related to the precipitation. In general, it is observed the streamflow and SSC simulated follows the trend of observed data, peaks depend on rainfall and suspended sediments depend on flow.

In terms of temporal dynamics in the sediment and heavy metals transport, Oka catchment showed a high temporal variability during the study period. Temporal variability of Ni load is related with SSC. The exportation rate, of both suspended sediments and $\mathrm{Ni}$, is lower than reported in other basins of the region.

The study of hydrology, suspended sediment and $\mathrm{Ni}$ transportation in Oka River catchment provides the understanding of the transport dynamics and factors conditioning the transport process. The discharge and suspended sediment yield modeling is important because it provides insight about Oka River catchment behavior in 

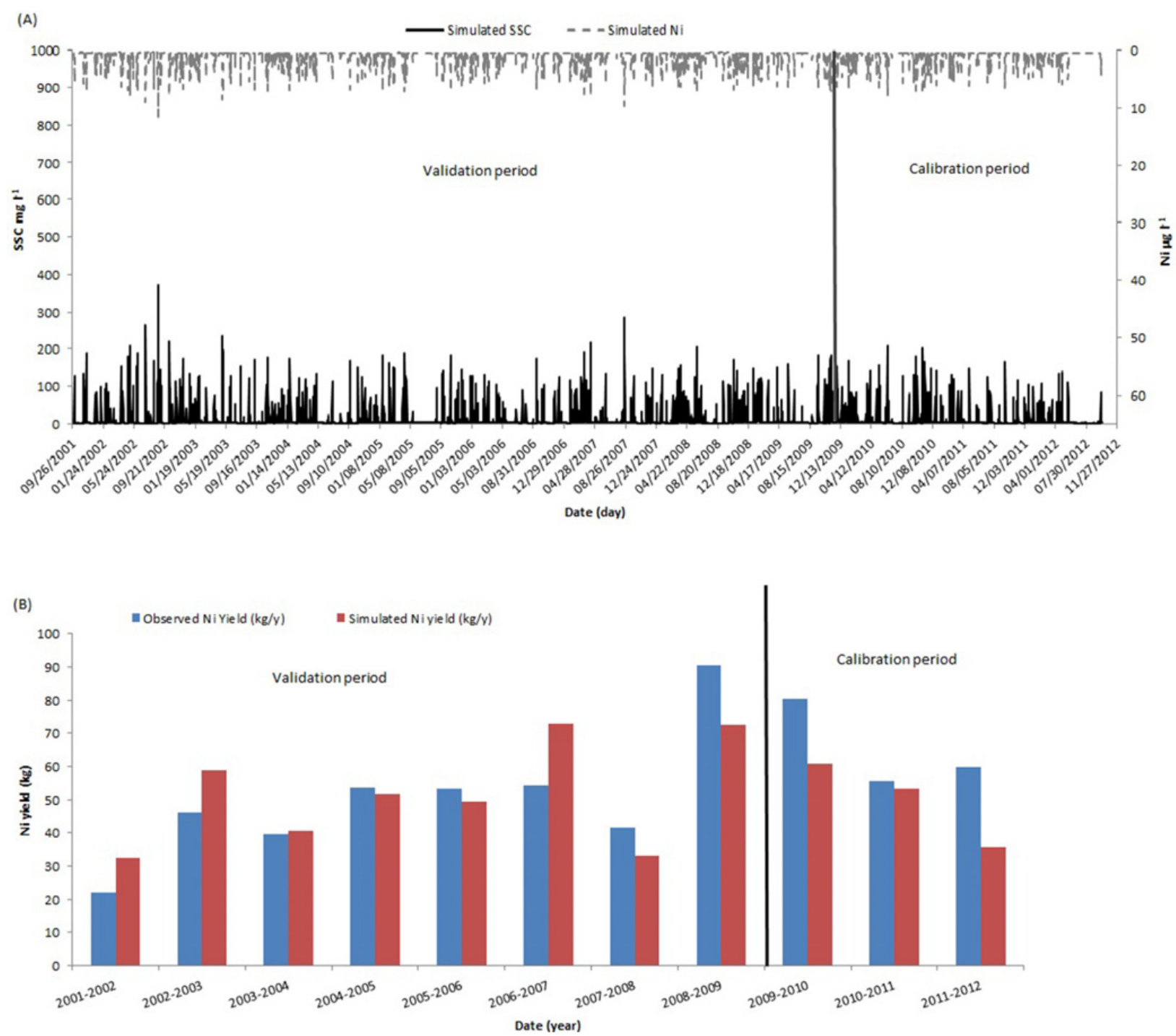

Fig. 6. Simulated daily suspended sediment concentration (SSC) and nickel (Ni) 2001-2012 (a) and simulated and observed annual Ni yield for Oka catchment during 2001-2012 (b).

terms of hydrologic response and mechanical soil erosion; this information is useful for determining suitable landuse and soil conservation measures for a catchment.

The SWAT project of the Oka catchment offers the possibility to extending this work to others problematic concerning with modeling of the impact of different climate scenarios on runoff and sediment yield and analysis of the quality water as nitrates, particulate organic carbon others heavy metals and fecal coliforms.

Acknowledgements. This research was financially supported by a doctoral scholarship from University of Costa Rica. The authors wish to thank the Ministry of Science and Innovation (project CG12011-26236), the Basque Government (Consolidated Group of Hydrogeology and Environment (IT598-13) and the University of the Basque Country UPV-EHU (UFI11/26) for supporting this research.

\section{References}

Agency for Toxic Substances and Disease Registry (ATSDR), 2005. Toxicological Profile for Nickel, U.S. Department of Health and Human Services, Public Health Service, Atlanta, GA. Available at http://www.atsdr.cdc.gov/ toxprofiles

Ankers C., Walling D.E. and Smith R.P., 2003. The influence of catchment characteristics on suspended sediment properties. Hydrobiologia, 494, 159-167.

Arnold J.G., Bircket M.D., Williams J.R., Smith W.F. and McGill H.N., 1987. Modeling the effects of urbanization on basin water yield and reservoir sedimentation. Water Resour. Bull., 23, 1101-1107.

Arnold J.G., Srinivasan R., Muttiah R.S. and Williams J.R., 1998. Large area hydrologic modeling and assessment Part I: model development. J. Am. Water Resour. Assoc., 34, 73-89. 
Arnold J.G., Kiniry J.R., Srinivasan R., Williams J.R. and Neitsch S.1., 2011. Soil and Water Assessment Tool: Input/ Output File Documentation Version 2009. USDA Agricultural Research Service and Texas A\&M Blackland Research Center, Temple. Available at http://swatmodel. tamu.edu/documentation

Arroyo L., Heidinger H. and Araya E.J., 2010. Modelo Hidrológico SWAT como herramienta para procesos de toma de decisión. Documento Técnico $\mathrm{N}^{\circ} 14$. Área de Evaluación de Tierras. Instituto Nacional de Innovación y Transferencia en Tecnología Agropecuaria, San José, Costa Rica.

ASCE, 1993. Criteria for evaluation of watershed models. J. Irrigation Drainage Eng., 119, 429-442.

Benaman J. and Shoemaker C.A., 2005. An analysis of high-flow sediment event data for evaluating model performance. Hydrol. Process., 19, 605-620.

Bizkaia Provincial Council (DFB). http:/www.bizkaia.net

Boskidis I., Gikas G.D., Sylaios G.K. and Tsihrintzis V.A., 2012. Hydrologic and water quality modeling of lower Nestos river basin. Water Resour. Manag., 26, 3023-3051.

Cánovas C.R., Olías M., Nieto J.M., Sarmient A.M. and Cerón J.C., 2007. Hydrogeochemical characteristics of the Tinto and Odiel Rivers (SW Spain). Factors controlling metal contents. Sci. Total Environ., 373, 363-382.

FAO. Available at http://www.fao.org/docrep/t2351 s/T2351S04. htm

Galván L., Olías M., Fernández de Villarán R., Domingo-Santos J.M., Nieto J.M., Sarmiento A.M. and Cánovas C.R., 2009. Application of the SWAT model to an AMD-affected river (Meca River, SW Spain). Estimation of transported pollutant load. J. Hydrol., 1377, 45-454.

GeoEuskadi, 2012. Territorial information system of the Basque Government. http://www.geo.euskadi.net/s69-15375/es

IRENAT, 2002. Empleo del Modelo SWAT para Generar Alternativas de Manejo en la.

Krause P., Boyle D.P., Base F., 2005. Comparison of different efficiency criteria for hydrological model assessment. $A d v$. Geosci., 5, 89-97.

Legates D.R., McCabe G.J., 1999. Evaluating the use of "goodness of fit" measures in hydrologic and hydroclimatic model validation. Water Resour. Res., 35, 233-241.

Mendiguchía C., Moreno C., García-Vargas M., 2007. Evaluation of natural and anthropogenic influences on Guadalquivir River (Spain) by dissolved heavy metals and nutrients. Chemosphere, 69, 1509-1517.

Montoya-Armenta L.H., 2013. Efectos de las avenidas en el transporte de material particulado y contaminantes asociados: aplicación al caso del río Oka (Urdaibai), País Vasco. Doctoral Thesis. Department of Chemical and Environmental Engineering, University of the Basque Country, Bilbao.

Moriasi D.N., Arnold J.G., Van Liew M.W., Binger R.L., Harmel R.D. and Veith T.L., 2007. Model evaluation guidelines for systematic quantification of accuracy in watershed simulations. Trans. ASABE, 50, 885-900.

Nadal-Romero E., Regüés D. and Latron J., 2008. Relationships among rainfall, runoff and suspended sediment in a small catchment with badlands. Catena, 74, 127-136.

Neitsch S.L., Arnold J.G., Kiniry J.R. and Williams J.R., 2011. Soil and Water Assessment Tool: Theoretical Documentation Version 2009. USDA Agricultural Research
Service and Texas A\&M Blackland Research Center, Temple. Available at http://swatmodel.tamu.edu/documentation/

Oeurng C., Sauvage S. and Sánchez-Pérez J.M., 2011. Assessment of hydrology, sediment and particulate carbon yield in a large agricultural catchment using SWAT model. J. Hydrol., 401, 145-153.

Olías M., Cánovas C.R., Nieto J.M. and Sarmiento A.M., 2006. Evaluation of the dissolved contaminant load transported by the Tinto and Odiel rivers (South West Spain). Appl. Geochem., 21, 1733-1749.

Parajuli P.B., Nelson N.O., Fress L.D. and Mankin K.R., 2009. Comparison of AnnAGNPS and SWAT model simulation results in USD-CEAP agricultural watersheds in south central Kansas. Hydrol. Process., 23, 748-763.

Qiu L.J., Zheng F.L. and Yin R.S., 2012. SWAT-based runoff and sediment simulation in a small watershed, the loessial hilly-gullied region of China: capabilities and challenges. Int. J. Sediment Res., 27, 226-234.

Rodríguez-Blanco M.L., Taboada-Castro M.M. and TaboadaCastro M.T., 2010. Factors controlling hydro-sedimentary response during runoff events in a rural catchment in the humid Spanish zone. Catena, 82, 206-217.

Rybicka E.H., Adamiec E. and Kwaterczak U., 2005. Distribution of trace metals in the Odra River system: Water-suspended matter-sediments. Limnologica, 35, 185-198.

Sadeghi S.H.R., Mizuyama T., Miyata S., Gomi T., Kosugi K., Fukushima T., Mizugaki S. and Onda Y., 2008. Determinant factors of sediment graphs and rating loops in a reforested watershed. J. Hydrol., 356, 271-282.

Santhi C.J., Arnold G., Williams J.R., Dugas W.A., Srinivasan R. and Hauck L.M., 2001. Validation of the SWAT model on a large river basin with point and nonpoint sources. J. Am. Water Resour. Assoc., 37, 1169-1188.

Spruill C.A., Workman S.R. and Taraba J.L., 2000. Simulation of daily and monthly stream discharge from small watersheds using the SWAT model. Trans ASABE, 43, 1431-1439.

Torres-Benites E., Fernández-Reynoso D., Oropeza-Mota J.L. and Mejía-Saenz E., 2003. Calibration of the hydrologic model SWAT in the watershed El Tejocote, Atlacomulco, Mexico. Terra Latinoamericana, 22, 437-444.

Uriarte A., 1998. Sediment dynamics on the inner continental shelf of the Basque Country (N. Spain). Doctoral Thesis. Department of Oceanography. Sciences Faculty. University of Southampton.

Walling D.A. and Webb B.W., 1996. Erosion and sediment yield: a global overview. IAHS Publ., 236, 3-19.

Williams G.P., 1989. Sediment concentration versus water discharge during single hydrologic events in rivers. J Hydrol., 111, 89-106.

Willmot C.J., 1981. On the validation of models. Phys. Geogr., 2, 184-194.

Willmot, C.J., 1984. On the evaluation of model performance in physical geography. Spat. Stat. Models, 443-460.

Winchell M., Srinivasan R., Di luzio M. and Arnold J., 2010. ArcSWAT Interface for SWAT 2009: User's Guide. Blackland Research Center, Texas Agricultural Experiment station and USD Agricultural Research Service. Available at http://swatmodel.tamu.edu/documentation/

Xu Z.X., Pang J.P., Liu C.M. and Li J.Y., 2009. Assessment of runoff and sediment yield in the Miyun Reservoir 
catchment by using SWAT model. Hydrol. Process., 23, 3619-3630.

Zabaleta A., Martínez M., Uriarte J.A. and Antigüedad I., 2007. Factors controlling suspended sediment yield during runoff events in small headwater catchments of the Basque Country. Catena, 71, 179-190.
Zabaleta A., Meaurio M., Ruiz-Romera E. and Antigüedad I., 2013. Simulation climate change impact on runoff and sediment yield in a small watershed in the Basque Country, northern Spain. J. Environ. Qual., 43, 235-245. DOI: 10.2134/ jeq2012.0209. 